\title{
Front Matter: Volume 8946
}

, "Front Matter: Volume 8946," Proc. SPIE 8946, Optical Elastography and Tissue Biomechanics, 894601 (13 March 2014); doi: 10.1117/12.2052752

SPIE. Event: SPIE BiOS, 2014, San Francisco, California, United States 


\title{
PROGRESS IN BIOMEDICAL OPTICS AND IMAGING
}

\section{Optical Elastography and Tissue Biomechanics}

\author{
Kirill V. Larin \\ David D. Sampson \\ Editors
}

1-2 February 2014

San Francisco, California, United States

Sponsored and Published by

SPIE 
The papers included in this volume were part of the technical conference cited on the cover and title page. Papers were selected and subject to review by the editors and conference program committee. Some conference presentations may not be available for publication. The papers published in these proceedings reflect the work and thoughts of the authors and are published herein as submitted. The publisher is not responsible for the validity of the information or for any outcomes resulting from reliance thereon.

Please use the following format to cite material from this book:

Author(s), "Title of Paper," in Optical Elastography and Tissue Biomechanics, edited by

Kirill V. Larin, David D. Sampson, Proceedings of SPIE Vol. 8946 (SPIE, Bellingham, WA, 2014) Article CID Number.

ISSN: 1605-7422

ISBN: 9780819498595

Published by

SPIE

P.O. Box 10, Bellingham, Washington 98227-0010 USA

Telephone +1 3606763290 (Pacific Time) · Fax +1 3606471445

SPIE.org

Copyright (@ 2014, Society of Photo-Optical Instrumentation Engineers.

Copying of material in this book for internal or personal use, or for the internal or personal use of specific clients, beyond the fair use provisions granted by the U.S. Copyright Law is authorized by SPIE subject to payment of copying fees. The Transactional Reporting Service base fee for this volume is $\$ 18.00$ per article (or portion thereof), which should be paid directly to the Copyright Clearance Center (CCC), 222 Rosewood Drive, Danvers, MA 01923. Payment may also be made electronically through CCC Online at copyright.com. Other copying for republication, resale, advertising or promotion, or any form of systematic or multiple reproduction of any material in this book is prohibited except with permission in writing from the publisher. The CCC fee code is $1605-7422 / 14 / \$ 18.00$.

Printed in the United States of America.

Publication of record for individual papers is online in the SPIE Digital Library.

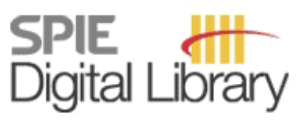

SPIEDigitalLibrary.org

Paper Numbering: Proceedings of SPIE follow an e-First publication model, with papers published first online and then in print and on CD-ROM. Papers are published as they are submitted and meet publication criteria. A unique, consistent, permanent citation identifier (CID) number is assigned to each article at the time of the first publication. Utilization of CIDs allows articles to be fully citable as soon as they are published online, and connects the same identifier to all online, print, and electronic versions of the publication. SPIE uses a six-digit CID article numbering system in which:

- The first four digits correspond to the SPIE volume number.

- The last two digits indicate publication order within the volume using a Base 36 numbering

system employing both numerals and letters. These two-number sets start with 00, 01, 02, 03, 04, $05,06,07,08,09,0 A, 0 B \ldots 0 Z$, followed by 10-1Z, 20-2Z, etc.

The CID Number appears on each page of the manuscript. The complete citation is used on the first page, and an abbreviated version on subsequent pages. Numbers in the index correspond to the last two digits of the six-digit CID Number. 


\title{
Contents
}

\author{
vii Conference Committee \\ ix Introduction
}

\section{OPTICAL COHERENCE ELASTOGRAPHY II: NOVEL METHODS}

894607 Visualization of ultrasonically induced shear wave propagation using phase sensitive optical coherence tomography [8946-6]

T.-M. Nguyen, Univ. of Washington (United States); S. Song, Univ. of Washington (United States) and Univ. of Dundee (United Kingdom); B. Arnal, E. Y. Wong, R. K. Wang, M. O'Donnell, Univ. of Washington (United States)

894608 Assessment of lamb wave dispersion in cornea using shear wave imaging optical coherence tomography (SWI-OCT) [8946-7]

S. Wang, Univ. of Houston (United States); K. V. Larin, Univ. of Houston (United States) and Baylor College of Medicine (United States)

\section{OCULAR BIOMECHANICS}

894609 Corneal biomechanical properties from air-puff corneal deformation imaging (Invited Paper) [8946-8]

S. Marcos, Instituto de Óptica, Consejo Superior de Investigaciones Científicas (Spain); S. Kling, Instituto de Óptica, Consejo Superior de Investigaciones Científicas (Spain) and Univ. de Genève (Switzerland); N. Bekesi, C. Dorronsoro, Instituto de Óptica, Consejo Superior de Investigaciones Científicas (Spain)

8946 OB Elastography methods applicable to the eye [8946-10] A. A. Khan, S. M. Cortina, Univ. of Illinois at Chicago (United States); W. Chamon, Univ. of Illinois at Chicago (United States) and Univ. Federal de São Paulo (Brazil); T. J. Royston, Univ. of Illinois at Chicago (United States)

\section{ELASTOGRAPHY METHODS AND APPLICATIONS}

8946 OF Laser speckle tracking for monitoring and analysis of retinal photocoagulation [8946-14] E. Seifert, K. Bliedtner, R. Brinkmann, Medical Laser Ctr. Lübeck GmbH (Germany)

8946 OG Ultrasound visualization of internal crystalline lens deformation using laser-induced microbubbles [8946-15]

A. B. Karpiouk, S. R. Aglyamov, The Univ. of Texas at Austin (United States); A. Glasser, Univ. of Houston (United States); S. Y. Emelianov, The Univ. of Texas at Austin (United States)

$8946 \mathrm{OH}$ Wideband optical elastography of in vivo human skin using geometrically focused surface waves [8946-16]

S. P. Kearney, Z. Dai, T. J. Royston, Univ. of Illinois at Chicago (United States) 
8946 Ol Evaluation of fingerprint deformation using optical coherence tomography [8946-17]

H. S. Gutierrez da Costa, Univ. Federal do Paraná (Brazil) and Stanford Univ. (United States);

J. R. Maxey, Stanford Univ. (United States); L. Silva, Univ. Federal do Paraná (Brazil);

A. K. Ellerbee, Stanford Univ. (United States)

\section{SUB-CELLULAR AND MEMBRANE BIOMECHANICS}

8946 OK Ultra-fast optical manipulation of single proteins binding to the actin cytoskeleton [8946-19] M. Capitanio, European Lab. for Non-linear Spectroscopy (Italy) and Univ. degli Studi di Firenze (Italy); L. Gardini, European Lab. for Non-linear Spectroscopy (Italy); F. S. Pavone, European Lab. for Non-linear Spectroscopy (Italy), Univ. degli Studi di Firenze (Italy), Istituto Nazionale di Ottica, CNR (Italy), and International Ctr. of Computational Neurophotonics (Italy)

8946 OM Linking cell shape, elasticity and fate: in vitro re-differentiation of chondrocytes [8946-21] X. Yuan, Y. Chim, H. Yin, Univ. of Glasgow (United Kingdom)

8946 OP Rate-dependent dynamics of cellular membranes probed by laser tweezers and optical displacement sensing [8946-24]

N. Khatibzadeh, Beckman Laser Institute and Medical Clinic (United States); A. A. Spector, Johns Hopkins Univ. (United States); W. E. Brownell, Baylor College of Medicine (United States); B. Anvari, Univ. of California, Riverside (United States)

\section{OPTICAL COHERENCE ELASTOGRAPHY III: ULTRASONIC LOADING}

8946 OT Model-based optical coherence elastography using acoustic radiation force [8946-28] S. Aglyamov, The Univ. of Texas at Austin (United States); S. Wang, Univ. of Houston (United States); A. Karpiouk, The Univ. of Texas at Austin (United States); J. Li, Univ. of Houston (United States); S. Emelianov, The Univ. of Texas at Austin (United States); K. V. Larin, Univ. of Houston (United States)

\section{CELLULAR BIOMECHANICS AND APPLICATIONS}

8946 OV Imaging the cellular response to transient shear stress using time-resolved digital holography [8946-30]

Y. Arita, M. Antkowiak, F. Gunn-Moore, K. Dholakia, Univ. of St. Andrews (United Kingdom)

8946 OW Dimensional characterisation of collagen constructs in situ [8946-31]

R. Taylor, J. Reynolds, B. Chikkanna, D. Daly, Lein Applied Diagnostics Ltd. (United Kingdom); R. A. Brown, N. S. Tan, Univ. College London (United Kingdom) 
POSTER SESSION

894610 Optical coherence tomography detection of shear wave propagation in MCF7 cell modules [8946-35]

M. Razani, A. Mariampillai, E. S. L. Berndl, Ryerson Univ. (Canada); T.-R. Kiehl, Univ. Health Network (Canada) and Univ. of Toronto (Canada); V. X. D. Yang, Ryerson Univ. (Canada) and Univ. of Toronto (Canada); M. C. Kolios, Ryerson Univ. (Canada)

894611 An OCT-based air suction-indentation probe for tissue elasticity measurement [8946-36] Y. Zheng, L. Wang, T. Li, The Hong Kong Polytechnic Univ. (Hong Kong, China); Y. Wang, Fudan Univ. (China)

Author Index 


\title{
Conference Committee
}

\author{
Symposium Chairs
}

James G. Fujimoto, Massachusetts Institute of Technology (United States)

R. Rox Anderson, Wellman Center for Photomedicine, Massachusetts General Hospital (United States) and Harvard School of Medicine (United States)

Program Track Chairs

Steven L. Jacques, Oregon Health \& Science University (United States) William P. Roach, U.S. Air Force (United States)

\section{Conference Chairs}

Kirill V. Larin, University of Houston (United States)

David D. Sampson, The University of Western Australia (Australia)

\section{Conference Program Committee}

Jeffrey C. Bamber, Institute of Cancer Research (United Kingdom)

A. Claude Boccara, Institut Langevin (France)

Stephen A. Boppart M.D., University of Illinois at Urbana-Champaign (United States)

Brett E. Bouma, Wellman Center for Photomedicine (United States)

Zhongping Chen, Beckman Laser Institute and Medical Clinic (United States)

Donald D. Duncan, Portland State University (United States)

Kishan Dholakia, University of St. Andrews (United Kingdom)

Daniel S. Elson, Imperial College London (United Kingdom)

Mathias Fink, Institut Langevin (France)

Brendan F. Kennedy, The University of Western Australia (Australia)

Sean J. Kirkpatrick, Michigan Technological University (United States)

Seemantini K. Nadkarni, Harvard Medical School (United States)

Kentaro Nakamura, Tokyo Institute of Technology (Japan)

Amy L. Oldenburg, The University of North Carolina at Chapel Hill (United States)

Francesco S. Pavone, European Laboratory for Non-linear Spectroscopy (Italy)

Giuliano Scarcelli, Harvard Medical School (United States)

Gijs van Soest, Erasmus MC (Netherlands)

Victor X. D. Yang, Ryerson University (Canada)

Seok Hyun A. Yun, Wellman Center for Photomedicine (United States)

Ruikang K. Wang, University of Washington (United States) 


\section{Session Chairs}

1 Optical Coherence Elastography I: Tissue Mechanical Contrast

Kirill V. Larin, University of Houston (United States)

David D. Sampson, The University of Western Australia (Australia)

2 Optical Coherence Elastography II: Novel Methods

Stephen A. Boppart M.D., University of Illinois at Urbana-Champaign (United States)

Zhongping Chen, Beckman Laser Institute and Medical Clinic (United States)

3 Ocular Biomechanics

Giuliano Scarcelli, Harvard Medical School (United States)

Ruikang K. Wang, University of Washington (United States)

4 Elastography Methods and Applications

Daniel S. Elson, Imperial College London (United Kingdom)

A. Claude Boccara, Institut Langevin (France)

5 Sub-Cellular and Membrane Biomechanics

Francesco S. Pavone, European Laboratory for Non-linear Spectroscopy (Italy)

Seok Hyun A. Yun, Wellman Center for Photomedicine (United States)

6 Optical Coherence Elastography III: Ultrasonic Loading

Victor X. D. Yang, Ryerson University (Canada)

Brendan F. Kennedy, The University of Western Australia (Australia)

7 Cellular Biomechanics and Applications

Amy L. Oldenburg, The University of North Carolina at Chapel Hill (United States)

Seemantini K. Nadkarni, Harvard Medical School (United States) 


\section{Introduction}

Optical elastography is the use of optics to characterize cells and tissues based on their elastic and viscoelastic mechanical properties. In utilizing the high-resolution capability of optics, this rapidly emerging field builds on and complements the related fields of ultrasound and MR elastography, as well as existing methods for biomechanics, such as atomic force microscopy and rheology.

Mechanical forces play an important role in the behavior and development of cells at all spatial scales, from cells and their constituents, to tissues and organs. Such forces profoundly influence the health, structural integrity, and normal function of cells and organs. Accurate determination of cell and tissue biomechanical properties (e.g., Young's or shear modulus) is a vitally important area. High-resolution optical methods could help further the understanding of mechanical interactions, and mechanical properties, with application to clinical diagnosis and interpretation of a wide range of diseases.

The inaugural subconference was very vibrant and displayed a strongly multidisciplinary character bringing together technology and application experts in bioengineering, biophysics, cell biology, clinical sciences, medical imaging, optics and photonics, and tissue engineering. More than 35 contributed papers were built around two days of invited and contributed talks. Exceptional invited talks headlined the contributed program:

- Stephen A. Boppart M.D., University of Illinois at Urbana-Champaign (United States) Optical coherence elastography techniques for assessing biomechanical properties of tissues and cells

- Susana Marcos, Consejo Superior de Investigaciones Científicas (Spain) Corneal biomechanical properties from air-puff corneal deformation imaging

- Kishan Dholakia, University of St. Andrews (United Kingdom) New light on cell manipulation and rheology

- Ruikang K. Wang, University of Washington (United States) Use of phase sensitive OCT to track and visualize dynamic mechanical wave propagation within tissue

Many topics were covered and highlights include the impressive advances in optical coherence elastography techniques, particularly in compression methods and shear wave visualization. Applications in the anterior eye proved popular, with some interest also in breast cancer. Optical elastography and tissue biomechanics confirmed its status as a rapidly emerging area-we look forward with excitement 
and anticipation to see what the next twelve months will bring. In the meantime, please enjoy reading the papers submitted for this volume.

Kirill V. Larin David D. Sampson 